\title{
Analisis Desain Formulir General Consent Rawat Inap (Studi Kasus di Lab RMIK Unjaya)
}

\author{
Kori Puspita Ningsih, Zakya Sinta Mahbubah \\ Universitas Jenderal Achmad Yani, Yogyakarta, Indonesia \\ Jl. Brawijaya, Ringroad barat, Ambarketawang, Gamping, Sleman \\ Korespondensi E-mail: puspitakori@gmail.com \\ Submitted: 31 Maret 2021, Revised: 17 Mei 2021, Accepted: 25 Juni 2021
}

\begin{abstract}
One of the forms that show the patient's consent or the patient's family and is related to the patient's right to obtain health services in the hospital is general consent. This study aims to determine the general consent function of inpatients and to analyze the design of the general consent form from physical, anatomical, and content aspects. This research is a descriptive study, with a case study approach in the Laboratory of Medical Records and Health Information (D-3), Faculty of Health, Jenderal Achmad Yani University, Yogyakarta. The results showed that general consent was used as material for inpatient registration practice for students of the RMIK Study Program (D-3). This activity is carried out to achieve the competence of Medical Record Management, which is carried out by the roleplay method. The results of the analysis of general consent on the physical, anatomical, and content aspects show that it is necessary to redesign general consent on the anatomy and content aspects, including: (1) changes in the placement of items on gender and blood group (2) additional information on how to fill in the checklist form on the instruction placed at the top of the form, (3) confirmation of important information by giving a Bold sign, (4) the name and logo of the hospital is updated (5) the identity of the person in charge is completed with gender, place of birth date and name, while the address of the immediate family is deleted, (6) additional information related to patient rights and obligations and other witness signatures.
\end{abstract}

Keyword: design analysis, general consent, inpatients

\begin{abstract}
Abstrak
Satu diantara formulir yang menunjukkan persetujuan pasien atau keluarga pasien dan berkaitan dengan hak kewajiban pasien untuk memperoleh pelayanan kesehatan di rumah sakit adalah general consent. Penelitian ini bertujuan mengetahui fungsi general consent pasien rawat inap dan menganalisis desain formulir general consent dari aspek fisik, anatomi dan isi. Penelitian ini merupakan penelitian deskriptif, dengan pendekatan studi kasus di Laboratorium Rekam Medis dan Informasi Kesehatan (D-3) Fakultas Kesehatan Universitas Jenderal Achmad Yani Yogyakarta. Hasil penelitian menunjukkan general consent digunakan sebagai bahan praktik pendaftaran pasien rawat inap mahasiswa Program Studi RMIK (D-3). Kegiatan tersebut dilakukan mencapai kompetensi Manajemen Rekam Medis yang dilaksanakan dengan metode roleplay. Hasil analisis general consent pada aspek fisik, anatomi dan isi menunjukkan perlu dilakukan desain ulang general consent pada aspek anatomi dan isi meliputi: (1) perubahan pada penempatan item pada jenis kelamin dan golongan darah (2) penambahan informasi cara pengisian ceklist formulir pada instruction yang diletakkan di bagian atas formulir, (3) penegasan informasi penting dengan pemberian tanda Bold, (4) nama dan logo rumah sakit diperbaharui (5) identitas penanggungjawab dilengkapi dengan jenis kelamin, tempat tanggal lahir, dan nama sedangkan alamat keluarga terdekat dihapus, (6) penambahan informasi terkait hak dan kewajiban pasien dan penambahan tanda tangan saksi.
\end{abstract}

Kata Kunci: analisis desain, general conset, rawat inap

\section{Pendahuluan}

Dalam upaya menghasilkan lulusan yang kompeten, maka Prodi RMIK (D-3) Fakultas Kesehatan Universitas Jenderal Achmad Yani Yogyakarta menyediakan pelayanan laboratorium Manajemen Informasi Kesehatan (MIK) untuk mendukung proses pembelajaran. Dalam penyelenggaraan pendidikan tenaga Perekam Medis harus tersedia bahan praktik satu diantaranya berkas rekam medis [1]. Saat ini laboratorium Prodi RMIK (D-3) Fakultas Kesehatan Universitas Jenderal Achmad Yani Yogyakarta menggunakan bahan praktik berkas rekam medis. 
Rekam medis digunakan dalam manajemen dan perencanaan fasilitas dan layanan perawatan kesehatan, untuk penelitian medis dan statistic kesehatan [2]. Selain itu rekam medis merupakan sarana untuk informasi utama atau pendokumentasian data di sarana pelayanan kesehatan [3]. Formulir merupakan alat yang digunakan dalam melakukan proses pencatatan dan pengolahan data rekam medis pasien. Untuk mendapatkan data rekam medis yang bermutu, aspek desain formulir yang baik perlu diterapkan dalam formulir rekam medis [4].

Berdasarkan pengambilan data awal diketahui bahwa laboratorium Prodi RMIK (D-3) Fakultas Kesehatan Universitas Jenderal Achmad Yani Yogyakarta memiliki General consent pasien rawat inap namun belum menjelaskan hak dan kewajiban pasien rawat inap. Hal ini tentunya berlum sesuai dengan dengan Permenkes Nomor 4 tahun 2018 tentang Kewajiban Rumah Sakit dan Kewajiban Pasien [5] dan Standar HPK 5 pada Standar Nasional Akreditasi Rumah Sakit yang menyampaikan bahwa Rumah sakit wajib meminta persetujuan umum (general consent) kepada pasien atau keluarganya pada saat pasien datang pertama kali untuk rawat jalan dan setiap rawat inap [6]. Penelitian ini bertujuan untuk mengetahui fungsi general consent pasien rawat inap dan menganalisis desain formulir general consent dari aspek fisik, anatomi dan isi.

\section{Metode Penelitian}

Jenis penelitian ini menggunakan penelitian deskriptif dengan pendekatan studi kasus. Metode penelitian ini digunakan untuk mendeskripsikan atau menggambarkan proses analisis dan perancangan ulang formulir general consent pasien rawat inap. Subjek penelitian ini adalah Ketua Prodi RMIK (D-3), Kepala Laboratorium, dan staf laboratorium Prodi RMIK (D-3) Fakultas Kesehatan Universitas Jenderal Achmad Yani Yogyakarta. Informan triangulasi pada penelitian ini adalah praktisi senior rekam medis di RSUD Tipe B Kota Yogyakarta. Objek pada penelitian ini adalah formulir general consent pasien rawat inap. Lokasi penelitian ini di Laboratorium Rekam Medis dan Informasi Kesehatan (D-3) Fakultas Kesehatan Universitas Jenderal Achmad Yani Yogyakarta. Penelitian dilaksanakan mulai bulan Juli sampai September 2020. Metode pengumpulan data pada penelitian ini menggunakan observasi dan wawancara. Observasi penelitian ini menggunakan instrumen pedoman observasi yang berupa checklist. Observasi dilakukan pada formulir general consent pasien rawat inap dengan menekankan pada analisis desain aspek fisik, anatomi dan isi. Peneliti juga melakukan wawancara menggunakan instrumen penelitian pedoman wawancara. Wawancara pada penelitian ini dilakukan dengan Ketua Prodi RMIK (D-3), Kepala Laboratorium, dan staf laboratorium. Pengolahan data pada penelitian ini diawali dengan editing, kemudian dilakukan klasifikasi dari hasil wawancara dan analisis desain formulir pada aspek fisik, anatomi dan isi, dan dilanjutkan dengan pengelompokkan data dan penyajian data dalam bentuk narasi.

\section{Hasil dan Pembahasan}

\section{Fungsi Formulir General Consent Pasien Rawat Inap}

Formulir general consent pasien rawat inap di Lab RMIK Universitas Jenderal Achmad Yani Yogyakarta merupakan formulir dalam bentuk kertas yang digunakan sebagai bukti administrasi pendaftaran pasien rawat inap. Formulir ini berfungsi sebagai bahan praktik skill mahasiswa Program Studi Rekam Medis dan Informasi Kesehatan (D-3) pada kegiatan praktik pendaftaran pasien rawat inap yang dilakukan dengan metode role play untuk memenuhi capaian pembelajaran Manajemen Rekam Medis. Hal ini sesuai dengan pernyataan informan berikut:

"kalau kami sebenarnya belum sepenubnya fungsi formulir general consentrawat inap, karena formulir yg ada saat ini hanya untuk bukti administrasi pendaftaran rawat inap saja, kemudian berkaitan dengan lab, formulir tersebut digunakan mahasiswa sebagai bahan pembelajaran praktik untuk mengetahui informasi apa saja yg wajib disampikan oleh petugas rekam medis saat melayani pasien di pendaftaran rawat inap, jadi supaya mahasiswa juga punya gambaran kebutuhan formulirnya seperti apa".

Kepala Lab RMIK 
Formulir general consent merupakan salah satu formulir yang wajib dimintakan persetujuan karena isinya menyangkut Hak dan Kewajiban pasien dan pelayanan kesehatan yang akan dilakukan terhadap pasien terkait dengan proses pemeriksaan, perawatan, dan pengobatan [7]. Pada Standar HPK 5 pada Standar Nasional Akreditasi Rumah Sakit yang menyampaikan bahwa pada saat pasien diterima waktu mendaftar rawat jalan dan setiap rawat inap, diminta menandatangani general consent. Rumah sakit memiliki dokumentasi dalam rekam medis tentang general consent [6].

Beberapa tugas pokok petugas di Tempat penerimaan Pasien Rawat Inap (TPPRI) yaitu bersama pasien dan keluarganya menetapkan ruang dan kelas perawatan yang diinginkan pasien dan tersedianya tempat tidur, untuk selanjutnya membuat surat persetujuan rawat inap [8]. Di Lab RMIK Universitas Jenderal Achmad Yani Yogyakarta, formulir tersebut digunakan sebagai bahan praktikum skill mahasiswa untuk kegiatan praktik pendaftara pasien rawat inap pada bahan kajian manajemen rekam medis, dan desain formulir rekam medis. Formulir rekam medis merupakan satu diantara bahan praktik yang diperlukan di laboratorium rekam medis [1].

\section{Analisis Formulir General Consent Pasien Rawat Inap}

Analisis formulir general consent pasien rawat inap dapat ditinjau dari aspek fisik, anotomi dan isi [4], [9]. Berikut ini adalah aspek fisik, aspek anatomi, dan aspek isi formulir general consent pasien rawat inap yang saat ini digunakan di lab RMIK Universitas Jenderal Achmad Yani Yogyakarta sesuai Gambar 1:

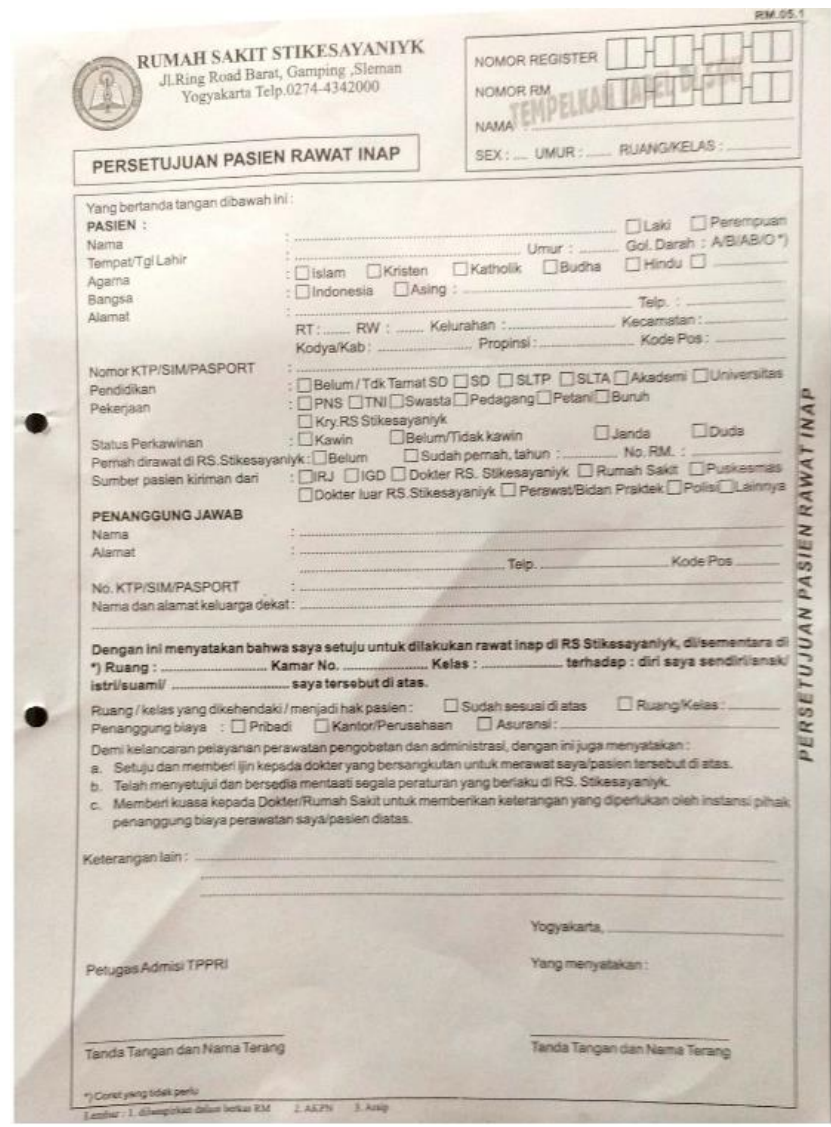

Gambar 1.

Formulir General Consent Rawat Inap di Lab RMIK

Universitas Jenderal Achmad Yani Yogyakarta 
a. Aspek Fisik

Berikut hasil analisis formulir general consent pasien rawat inap pada aspek fisik (Tabel 1):

Tabel 1.

Aspek Fisik Formulir General Consent Pasien Rawat Inap

\begin{tabular}{cll}
\hline No & Aspek Fisik & Hasil \\
\hline 1 & Bahan & Kertas HVS 80 gram \\
2 & Bentuk & $\begin{array}{l}\text { Menyerupai buku berbentuk persegi panjang dengan lebar } 21 \mathrm{~cm} \\
\text { dan panjang } 29,7 \mathrm{~cm}\end{array}$ \\
3 & Ukuran & A4 \\
4 & Warna & Putih \\
\hline
\end{tabular}

Bahan formulir general consent pasien rawat inap di lab RMIK Universitas Jenderal Achmad Yani Yogyakarta menggunakan bahan kertas HVS 70 gram. Bahan tersebut cukup tebal dan tidak mudah rusak dan sobek. Hasil penelitian sebelumnya yang dilakukan oleh Subinarto dkk dengan judul "Analisis Desain Formulir Ringkasan Masuk dan Keluar Rawat Inap" menunjukkan bahwa desain formulir ringkasan masuk keluar dengan bahan kertas HVS 70 gram membuat formulir mudah sobek [4].

Bentuk formulir general consent pasien rawat inap di lab RMIK Universitas Jenderal Achmad Yani Yogyakarta Menyerupai buku berbentuk persegi panjang dengan lebar $21 \mathrm{~cm}$ dan panjang 29,7 cm, ukuran A4 berwarna putih. Hal ini mendukung penelitian sejenis yang dilakukan oleh Faiqatul Hikmah dkk dengan judul "Desain Formulir Asesmen Nyeri dalam Berkas Rekam Medis di Rumah Sakit Daerah Balung Jember Tahun 2016" menunjukkan desain formulir assasmen nyeri menggunakan kertas HVS 70 gram, berwarna putih dengan ukuran lebar 21,5 cm dan panjang 29,7 cm [10].

Penelitian Endah puspitasari dkk dengan judul "Perancangan Desain Formulir Rekam Medis Pasien Rawat Jalan Poliklinik Umum Di Puskesmas Kauman Kabupaten Ponorogo" menjelaskan bahwa perancangan desain formulir rekam medis pasien rawat jalan poliklinik umum menggunakan kertas HVS berukuran lebar $22 \mathrm{~cm}$ dan panjang $34 \mathrm{~cm}$ dengan berat kertas 80 gram dengan tinta berwarna hitam, formulir warna merah muda untuk perempuan dan biru untuk laki-laki [11] 
b. Aspek Anatomi

Berikut hasil analisis formulir general consent pasien rawat inap pada aspek anatomi (tabel 2):

Tabel 2.

Aspek Anatomi Formulir General Consent Pasien Rawat Inap

\begin{tabular}{|c|c|c|}
\hline No & Aspek Anatomi & Hasil \\
\hline 1 & Heading & $\begin{array}{l}\text { Terdapat logo, nama, alamat, dan nomor telepon namun belum } \\
\text { update }\end{array}$ \\
\hline 2 & Introduction & Terdapat judul formulir "Persetujuan Pasien Rawat Inap" \\
\hline 3 & Intruction & Belum terdapat informasi cara pengisian ceklist pada formulir \\
\hline 4 & Body & $\begin{array}{l}\text { Terdapat beberapa informasi yang terdapat pada satu baris yang sama, } \\
\text { sehingga space kurang jelas, seperti (1) nama yang sejajr dengan jenis } \\
\text { kelamin, (2) Tempat tanggal lahir sejajar dengan umur dan Golongan } \\
\text { darah, (3) Alamat sejajar dengan nomor telepon padahal di baris } \\
\text { selanjutnya masih ada item kelengkapan alamat }\end{array}$ \\
\hline 5 & Font & $\begin{array}{l}\text { Font yang digunakan menggunakan Times New Roman ukuran } 14 \\
\text { untuk identitas formulir, Arial ukuran } 14 \text { untuk identitas pasien dan } \\
\text { judul formulir, Arial ukuran } 11 \text { untuk isi formulir. Terdapat beberapa } \\
\text { font yang diberi tanda Bold sebagai penegasan dari informasi pada } \\
\text { formulir. }\end{array}$ \\
\hline 6 & Ruler & $\begin{array}{l}\text { Terdapat ruler pada formulir untuk membatasi heading dan body } \\
\text { formulir }\end{array}$ \\
\hline 7 & Border & Terdapat border dalam formulir \\
\hline
\end{tabular}

Pada bagian heading formulir menjelaskan identitas formulir masih menggunakan nama "Rumah Sakit StikesAyaniYK" dan logo Stikes Jenderal Achmad Yani. Pada identitas formulir tersebut sebaiknya menggunakan identitas dan logo Universitas jenderal Achmad Yani Yogyakarta. Hal ini sesuai pernyataan informan berikut:

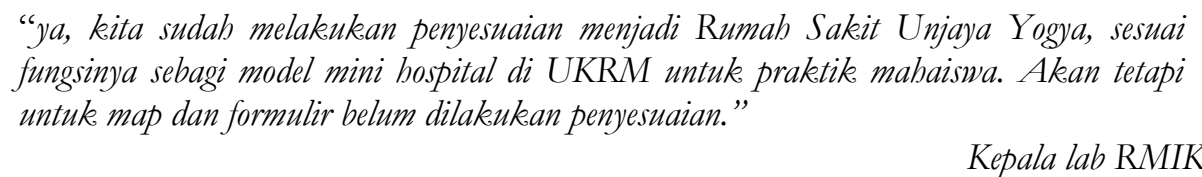

Dengan belum adanya penyesuaian tersebut tentunya berdampak identitas formulir tidak akurat [12]. Pada bagian introduction terdapat judul formulir "Persetujuan Pasien Rawat Inap" dan pada intruction belum terdapat informasi craa pengisian ceklist pada formulir. Informasi pada introduction dan intruction berfungsi sebagai penjelasan dari tujuan formulir [13]. Identifikasi dan instruksi umum harus disingkat dan berada pada bagian atas formulir, instruksi yang panjang biasa diletakkan pada lembaran atau buku [11].

Pada body terdapat beberapa informasi yang terdapat pada satu baris yang sama, sehingga space kurang jelas, seperti nama yang sejajar dengan jenis kelamin, dan tempat tanggal lahir sejajar dengan umur dan golongan darah, alamat sejajar nomor telepon padahal di baris selanjutnya masih ada item 
kelengkapan alamat. Hal ini berpotensi terjadinya ketidaklengkapan pengisian karena pembaca yang kurang teliti atau tidak terbaca saat mengisi formulir. Oleh karena itu perlu dilakukan desain ulang terkait penempatan item supaya memudahkan pembaca dalam mengisi item formulir.

Font yang digunakan menggunakan Times New Roman ukuran 14 untuk identitas formulir, Arial ukuran 14 untuk identitas pasien dan judul formulir, Arial ukuran 11 untuk isi formulir. Terdapat beberapa font yang diberi tanda Bold sebagai penegasan dari informasi pada formulir. Font berkaitan dengan jenis huruf. Hal ini akan bedampak pada keterbacaan. Oleh sebab itu perlu diperhatikan ukuran, penebalan huruf, huruf miring, dan lain sebagainya [13].

Terdapat ruler pada formulir untuk membatasi heading dan body formulir. Ruler dibuat langsung tanpa menggunakan garis putus-putus sehingga lebih jelas dan menunjukkan penekanan pada setiap item [9]. Rules ditunjukkan dengan garis vertical dan borizontal yang berfungsi untuk membagi form ke dalam bagian-bagian dan mengarahkan entry lokasi [13].

c. Aspek Isi

Berikut hasil analisis formulir general consent pasien rawat inap pada aspek isi (Tabel 3):

Tabel 3.

Aspek Isi Formulir General Consent Pasien Rawat Inap

\begin{tabular}{|c|c|c|}
\hline No & Aspek Isi & Hasil \\
\hline 1 & $\begin{array}{l}\text { Identitas sarana pelayanan } \\
\text { kesehatan }\end{array}$ & $\begin{array}{l}\text { Sudah tersedia identitas nama sarana pelayanan kesehatan, } \\
\text { pada bagian heading nama belum update }\end{array}$ \\
\hline 2 & Identitas Pasien & $\begin{array}{l}\text { Identitas pasien meliputi Nama, Jenis kelamin, Tempat } \\
\text { tanggal lahir, Umur, Golongan darah, Agama, bangsa, } \\
\text { Alamat, Nomot Telepon, Nomor KTP, pendidikan, } \\
\text { pekerjaa, Status perkawinan, Status pernah dirawat, Sumber } \\
\text { pasien. }\end{array}$ \\
\hline 3 & Identitas Penanggungjawab & $\begin{array}{l}\text { Terdapat Nama, Alamat, Nomor Telepon, Nomor KTP, } \\
\text { Nama dan alamat keluarga terdekat }\end{array}$ \\
\hline 4 & $\begin{array}{l}\text { Informasi persetujuan rawat } \\
\text { inap }\end{array}$ & $\begin{array}{l}\text { Sudah terdapat informasi persetujuan rawat inap tetapi } \\
\text { belum menjelaskan informasi mengenai hak dan kewajiban } \\
\text { pasien }\end{array}$ \\
\hline 5 & Autentifikasi & $\begin{array}{l}\text { Terdapat item nama dan tangan tangan petugas TPP dan } \\
\text { Pasien/Wali yang menyatakan }\end{array}$ \\
\hline 6 & Singkatan & $\begin{array}{l}\text { Terdapat penggunaan singkatan yang sudah umum } \\
\text { digunakan pada item pendidikan seperti singkatan SD, SLTP, } \\
\text { SLTA, dan item sumber pasien seperti IRJ dan IGD. }\end{array}$ \\
\hline
\end{tabular}

Pada aspek isi menjelaskan kelengkapan item pada formulir [11]. Aspek isi formulir meliputi kelengkapan item, terminologi, singkatan, dan simbol [4]. Komponen tersebut sudah terdapat pada formulir general consent pasien rawat inap di lab RMIK Universitas Jenderal Achmad Yani Yogyakarta. Pada indentitas sarana pelayanan kesehatan perlu dilakukan desain ulang untuk mengupdate identitas nama dan logo rumah sakit. Selanjutnya untuk identitas pasien sudah mencakup minimal 2 dari 3 komponen yaitu Nama, Nomor rekam medis, Tanggal lahir [6]. Sedangkan identitas penanggungjawab perlu dilengkapi dengan jenis kelamin dan tempat tanggal lahir. Sedangkan untuk nama dan alamat keluarga terdekat tidak perlu supaya tidak bias dengan identitas penanggungjawab/wali. 
Informasi persetujuan rawat inap sudah ada tetapi belum menjelaskan informasi mengenai hak dan kewajiban pasien. Beberapa hak pasien atau keluarga di institusi pelayanan kesehatan meliputi mendapatkan informasi mengenai tata tertib dan peraturan yang berlaku di rumah kakit, mendapatkan informasi tentang hak dan kewajiban pasien, memilih dokter dan kelas perawatan sesuai dengan keinginannya dan peraturan yang berlaku di rumah sakit, mendapat informasi yang meliputi diagnosis dan tata cara tindakan medis,tujuan tindakan medis, alternatif tindakan, risiko dan komplikasi yang mungkin terjadi, dan prognosis terhadap tindakan yang dilakukan serta perkiraan biaya pengobatan, memberikan persetujuan atau menolak atas tindakan yang akan dilakukan oleh tenaga kesehatan terhadap penyakit yang dideritanya [14], [5]. Pada HPK 5 disampaikan bahwa rumah sakit wajib meminta persetujuan umum (general consent) kepada pasien atau keluarganya berisi persetujuan terhadap tindakan yang berisiko rendah, prosedur diagnostik, pengobatan medis lainnya, batas-batas yang telah ditetapkan, dan persetujuan lainnya [6].

Pada autentifikasi formulir general consent pasien rawat inap di lab RMIK Universitas Jenderal Achmad Yani Yogyakarta hanya terdapat item nama dan tangan tangan petugas TPP dan Pasien/Wali yang menyatakan tanpa adanya tanda tangan saksi. Autentifikasi diantaranya nama dan tanda tangan saksi yaitu dokter selaku pemberi informasi dan Pasien/keluarga pasien selaku penerima informasi dan saksisaksi [15]. Oleh karena itu perlu dilakukan desain ulang dengan menambahkan tanda tangan saksi dari pihak rumah sakit maupun dari pihak keluarga pasien.

Penggunaan singkatan pada formulir general consent pasien rawat inap di lab RMIK Universitas Jenderal Achmad Yani Yogyakarta menggunakan singkatan yang umum digunakan seperti SD, SLTP, SLTA, IRJ dan IGD. Menurut standar MIRM12 ep 5 disampaikan bahwa rumah sakit diminta memiliki daftar singkatan yang diperkenankan dan dilarang [6].

\section{Desain ulang Formulir General Consent Pasien Rawat Inap}

Berdasarkan hasil analis desain formulir general consent pasien rawat inap di lab RMIK Universitas Jenderal Achmad Yani Yogyakarta dari aspek fisik, anatomi dan isi dapat disimpulkan perlu dilakukan resedain formulir general consent pasien rawat inap untuk memenuhi kebutuhan desain formulir. Hal ini tentunya juga mendukung capaian pembelajaran Prodi RMIK (D-3) Fakultas Kesehatan Universitas Jenderal Achmad Yani Yogyakarta yaitu mampu mengikuti perkembangan IPTEK di bidang rekam medis untuk menghadapi persaingan global (P04) [16].

Peneliti mengusulkan 2 desain ulang formulir general consent pasien rawat inap. Setelah dilakukan brainstorming, dan divaiadasi oleh informan triangulasi yaitu praktisi seniot berlatar belakang rekam medis di RSUD Tipe B di wilayah DIY, maka berikut hasil redasin formulir general consent pasien rawat inap yang sudah disepakati.

Pada gambar 2 dan 3 dapat disampaikan bahwa desain ulang formulir general consent pasien rawat inap dilakukan pada: (1) aspek anatomi, yaitu desain ulang pada penempatan item supaya memudahkan pembaca dalam mengisi item formulir meliputi jenis kelamin ditempatkan terpisah pada baris yang berbeda dengan nama, golongan darah ditempatkan terpisah pada baris yang berbeda dengan tempat tanggal lahir dan umur, penambahan informasi cara pengisian ceklist formulir pada instruction yag diletakkan di bagian atas formulir, serta penegasan informasi penting dengan pemberian tanda Bold, (2) aspek isi, yaitu nama dan logo rumah sakit diupdate menggunakan nama 'Rumah Sakit Unjaya Yogyakarta" dengan Logo Universitas Jenderal Achmad Yani Yogyakarta, identitas penanggungjawab dilengkapi dengan jenis kelamin dan tempat tanggal lahir, nama dan alamat keluarga terdekat dihapus, penambahan informasi terkait hak dan kewajiban pasien dan penambahan tanda tangan saksi I (pihak pasien) dan saksi II (pihak rumah sakit). 


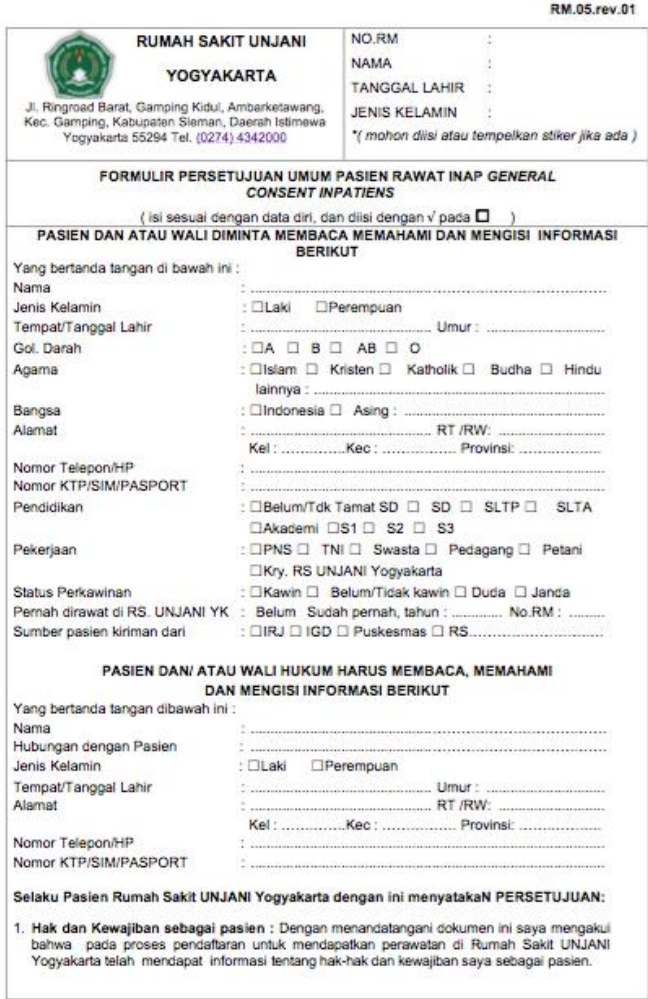

Gambar 2.

Halaman 1 Formulir General consent Pasien Rawat Inap

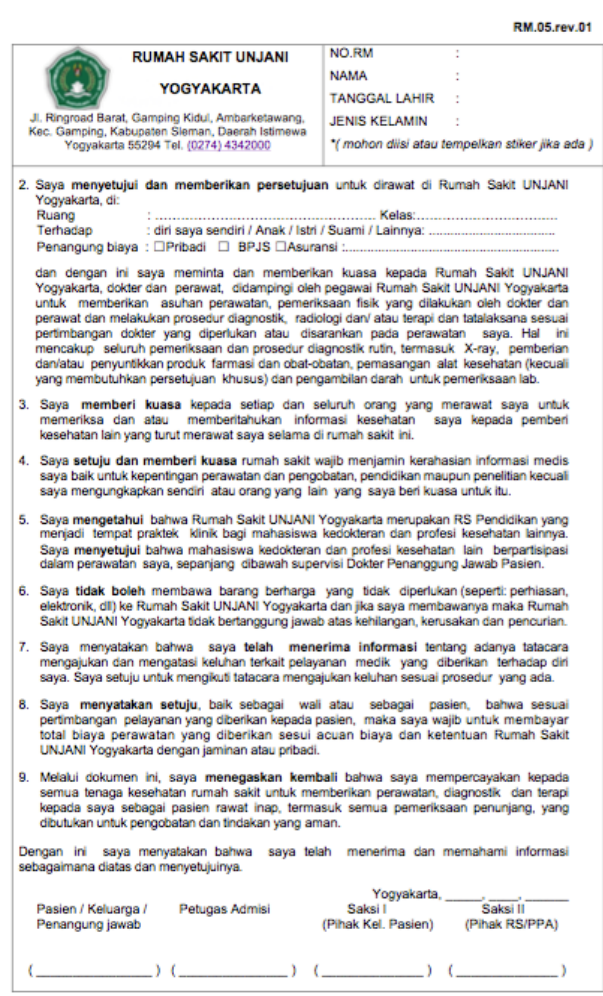

Gambar 3.

Halaman 2 Formulir General Consent Pasien Rawat Inap

\section{Kesimpulan}

Formulir general consent di Lab RMIK Universitas Jenderal Achmad Yani Yogyakarta digunakan sebagai bahan praktik pendaftaran pasien rawat inap mahasiswa Program Studi Rekam Medis dan Informasi Kesehatan (D-3).Kegiatan tersebut dilakukan mencapai kompetensi Manajemen Rekam Medis yang dilaksanakan dengan metode roleplay. Hasil analisis general consent pada aspek fisik, anatomi dan isi menunjukkan perlu dilakukan desain ulang general consent pada aspek anatomi dan isi yang meliputi: (1) perubahan pada penempatan item supaya memudahkan pembaca dalam mengisi item formulir meliputi jenis kelamin ditempatkan terpisah pada baris yang berbeda dengan nama, golongan darah ditempatkan terpisah pada baris yang berbeda dengan tempat tanggal lahir dan umur, (2) penambahan informasi cara pengisian ceklist formulir pada instruction yag diletakkan di bagian atas formulir, (3) penegasan informasi penting dengan pemberian tanda Bold, (4) nama dan logo rumah sakit diupdate menggunakan nama "Rumah Sakit Unjaya Yogyakarta" dengan Logo Universitas Jenderal Achmad Yani Yogyakarta, (5) identitas penanggungjawab dilengkapi dengan jenis kelamin dan tempat tanggal lahir, nama dan alamat keluarga terdekat dihapus, (6) penambahan informasi terkait hak dan kewajiban pasien dan penambahan tanda tangan saksi I (pihak pasien) dan saksi II (pihak rumah sakit).

\section{Daftar Pustaka}

1. Kemenkes. Surat Keputusan Menteri Kesehatan Republik Indonesia No. HK.03.05/IV/14354.1/2010 tanggal 31 Desember 2010 tentang Standar Laboratorium Pendidikan Tenaga Kesehatan. 2010.

2. WHO. Medical Records Manual: A Guide for Developing Countries. Geneva: WHO Library Cataloguing in Publication Data, 2017.

3. Hatta GR. Pedoman Manajemen Informasi Kesehatan di Sarana Pelayanan Kesehatan. Jakarta: Universitas Indonesia, 2017. 
4. Subinarto. Analisis Desain Formulir Ringkasan Masuk dan Keluar Rawat Inap Poltekkes Kemenkes Semaran , 2) RS Palang Biru Kutoarjo. J Rekam Medis dan Inf Kesehat 2018; 1: 76-81.

5. Kemenkumham, HAM KH dan. Peraturan Menteri Kesehatan Republik Indonesia Nomor 4 tahun 2018 Tentang Kewajiban Rumah Sakit dan Kewajiban Pasien. Jakarta, Jakarta, 2018.

6. KARS. Standar Nasional Akreditasi Rumah Sakit Edisi 1. Jakarta: KARS, 2017, pp. 1-421.

7. Yulia N, Nurazizah D. Tinjauan Penjelasan General Consent Di Pendaftaran Rawat Inap Rs Medika Permata Hijau. Pros Semin Nasinal rekam Medis dan Inf Kesehat Penguatan Pendidik Tenaga Kesehat di Era Ind 40; 17-22.

8. Hastuti.S., Antik Pujihastuti Ri. Prediksi Kebutuhan Formulir Rekam Medis Rawat Inap di RSUD kabupaten Karanganyar. J Kesehat 2009; 3: 1-22.

9. Nissaa K, Lestar T, Mulyono S. Pengembangan Desain Map Rekam Medis (Folder) dengan Kode Warna Di RSUD Pandan Arang Boyolali. 2014; 158.

10. Hikmah F, Wijayanti RAW, Laksono MJC. Desain Formulir Asesmen Nyeri Dalam Berkas Rekam Medis di Rumah Sakit Daerah Balung Jember Tahun 2016. J Kesehat 2019; 5: 138-148.

11. Puspitasari;etall. Perancangan Desain Formulir Rekam Medis Pasien Rawat Jalan Poliklinik Umum Di Puskesmas Kauman Kabupaten Ponorogo. Glob Heal Sci 2017; 2: 87-90.

12. Abdelhak M. Health Information: Management of a Strategic Resource. Missouri: Saunders Elsevier, 2016.

13. Rustiyanto E. Manajemen Filing Dokumen Rekam Medis dan Informasi Kesehatan. Yogyakarta: Politeknik Kesehatan Permata Indonesia, 2011.

14. Menkes RI, Kemenkes. UU RI No 44 Tahun 2009 tentang Rumah Sakit.

15. Herfiyanti L. Kelengkapan Informed Consent Tindakan Bedah Menunjang Akreditasi Jci Standar Hpk 6 Pasien Orthopedi. J Manaj Inf Kesehat Indones 2015; 3: 81-88.

16. Prodi RMIK. Surat Keputusan Nomor: Skep 054/FKES/VIII/ 2019 tentang Kurikulum Pendidikan Program Studi Perekam dan Infokes (D-3) Fakultas Kesehatan Universitas Jenderal Achmad Yani Yogyakarta. 2019. 